\title{
Bloomfield, Leonard \\ Lenguaje \\ XII + 684 pp. Lima: Universidad \\ Nacional Mayor de San Marcos, 1964.
}

Recenseado por Aryon D. Rodrigues

Esta é a tradução para o espanhol de um dos grandes, clássicos da linguística. Publicado em 1933, como edição revista de uma introdução ao estudo da linguagem (Introduction to the study of language, Nova Iorque, 1914), Language de Bloomfield se firmou como o melhor manual de linguística durante um quarto de século. Só nos últimos anos têm aparecido alguns manuais que se lhe comparam na cobertura ampla e segura dos vários aspectos da ciência da linguagem. Os manuais surgidos na Europa, pouco antes ou depois dele, ignoravam completamente o desenvolvimento que vinha tendo a linguística na América do Norte, ao passo que Bloomfield, de excelente formação linguística europeia, mas ao mesmo tempo atento para os problemas da investigação das línguas indígenas americanas e sistematizador, ele mesmo, do estudo descritivo das estruturas linguísticas, conjugou, em estilo didático, as aquisições da linguística europeia com a experiência linguística americana. Isto é posto em evidência, aliás, pelo Dr. Alberto Escobar, professor de Filologia e Linguística na Universidade de São Marcos, o qual reviu e prefaciou esta tradução:

Mas também nenhum livro norte-americano poderia evocar em conjunto, tão ao vivo, o clima internacional que preside o movimento linguístico de nosso século, nem as notáveis coincidências que devemos relembrar. Ler Language é não só penetrar num dos grandes livros de linguística de todos os tempos, mas também tomar intimidade com um 
espírito amplo, generoso, pairando acima das fronteiras e dos egoísmos miúdos. Lendo-o se atualizam as contribuições do Círculo de Praga, da Escola Dinamarquesa, do grupo de Londres, de Genebra, dos Países Baixos, de Moscou e Leningrado, e de Paris. Lendo-o se aprende uma lição de respeito ao pensamento do ser humano, e de inteligente colóquio com as ideias e os tempos. (p. XIV).

Ao justificar a escolha deste manual para publicação pela Universidade de São Marcos, diz Escobar que esta se fez "a) em primeiro lugar, pelo mérito intrínseco da obra e o notável influxo que dela deriva para a linguística contemporânea; e, b) porque nenhum outro texto seria mais apropriado para estabelecer uma aproximação sistemática ao processo de realizações cumprido pelos colegas norte-americanos" (p. VII). E acrescenta: "Language é, sem a menor dúvida, um ponto de chegada, no qual se organiza o saber acumulado por gerações de estudiosos de diversos países, mas é, ao mesmo tempo, e aí está a razão de sua importância, um ponto de mudança de rumo, a partir do qual se desenvolvem métodos e atitudes que hoje são aquisições permanentes da ciência linguística, do mesmo modo que são fundamento imprescindível para entender e aproveitar o que, com rótulo apressado, se chama "linguística norte-americana" (p. VII).

Não é minha intenção fazer uma recensão da obra de Bloomfield. Quaisquer estudantes de linguística se inteiram hoje em dia, em qualquer curso introdutório ou em qualquer manual mais recente, da considerável importância dessa obra e, consequentemente, da imperiosa necessidade de empreender sua leitura. Acontece, porém, que até agora só existia Bloomfield em inglês e grande parte dos que deverão tirar proveito desta obra não se acham em condições, num país como o nosso, de enfrentar um texto longo nessa língua. Daí a necessidade que sentíamos há algum tempo de fazer traduzir para o português, entre outros, o livro de Bloomfield. Em 1960 sugeriu-me Mattoso Câmara Jr. esse empreendimento, mas não tive ocasião de iniciá-lo, embora tenha procurado, por minha vez, quem quisesse aceitá-lo. Entretanto, já em 1963, anunciava-me Escobar que estava em andamento a publicação da presente tradução espanhola, a qual certamente será tão útil aos leitores brasileiros quanto o é aos hispano-americanos, já que a língua espanhola, à diferença da inglesa, não constitui entre nós nenhuma barreira linguística séria. Esta a razão muito particular porque recomendamos Lenguaje a todos os que, no Brasil, não têm acesso ao texto original.

Esta tradução é enriquecida não só pelo prólogo da autoria de Alberto Escobar, o qual, além de orientar o leitor sobre a obra que vai ler, faz considerações sobre as tarefas da linguística no Peru, em grande parte válidas 
também para o Brasil; mas ainda pelo acréscimo de uma bibliografia básica complementar (pp. 658-661), elaborada igualmente por Escobar, a qual "pretende informar o interessado acerca das principais orientações que continuam Bloomfield na linguística moderna dos Estados Unidos". (O livro pode ser pedido à Librería de la Universidad de San Marcos, Jirón Cuzco, n 676, Lima, Peru. Preço: 6 dólares). 